\title{
Evaluation of bovine Parainfluenza type-3 virus and Influenza virus D participation in bovine respiratory disease of calves from Brazilian family farming
}

\author{
[Avaliação da participação do Parainfluenza vírus do tipo 3 e do Influenza vírus $D$ na doença \\ respiratória dos bovinos de bezerros de agricultura familiar]
}

\section{"Artigo Científico/Scientific Article"}

\author{
Natália Carrillo Gaeta ${ }^{1 *}$, Bruno Leonardo Mendonça Ribeiro ${ }^{1}$, Mario Augusto Reyes Alemán ${ }^{1}$, \\ Luciano Matsumiya Thomazelli $^{2}$, Edson Luiz Durigon ${ }^{2}$, Adriana Hellmeister de Campos Nogueira ${ }^{3}$, \\ Eliana de Stefano $^{3}$, Liria Hiromi Okuda ${ }^{3}$, Edviges Maristela Pituco ${ }^{3}$, Lilian Gregory ${ }^{1}$ \\ ${ }^{1}$ Departamento de Clínica Médica, Faculdade de Medicina Veterinária e Zootecnia, Universidade de São Paulo (USP), \\ São Paulo-SP, Brasil. \\ ${ }^{2}$ Laboratório de Virologia, Departamento de Microbiologia, Instituto de Ciências Biomédicas, Universidade de São Paulo \\ (USP), São Paulo-SP, Brasil. \\ ${ }^{3}$ Laboratório de Viroses de Bovídeos, Instituto Biológico de São Paulo-SP, Brasil. \\ *Autor para correspondência/Corresponding author: E-mail: natalia.gaeta@ @otmail.com
}

\begin{abstract}
Bovine respiratory disease (BRD) is responsible for great economic losses in bovine production with major impact on family farming. Among all possible causes of bovine respiratory disease, viruses are commonly categorized as primary etiological agents. The present study aimed to identify the presence of bovine parainfluenza type 3 virus and Influenza virus D (IVD) in tracheobronchial fluid samples of healthy calves and calves showing clinical signs of bovine respiratory disease. Samples were collected from 42 family farming farms in São Paulo State, Brazil. A total of 141 tracheobronchial fluid samples from healthy calves ( $\mathrm{n}=100)$ and calves showing clinical signs of bovine respiratory disease $(n=41)$ were enrolled in this study. No sample was positive for both viruses after Real-Time PCR. Serum neutralization for bovine Parainfluenza type 3 virus (bPI-3v) was performed using 88 randomly selected serum samples and antibodies were detected in $45.45 \%$ (40/88) samples. Serum reactive samples were detected in both healthy $(46.8 \% ; 22 / 47)$ and BRD calves $(43.9 \% ; 18 / 41)$. Regarding antibody titer, numerical differences were detected between healthy $(3 \%)$ and BRD calves $(9 \%)$ for titers 128-512 $(\mathrm{P}>0.05)$. The present research was the first that aimed to study the presence of bPI-3V and IVD in family farming herds from São Paulo State, Brazil. This research revealed that bPI-3v is circulating in the region studied and is possibly involved in some BRD cases. On the other hand, IVD was not detected.
\end{abstract}

Keywords: viruses; pneumonia; bovine production; Real-time PCR; tracheobronchial fluid samples.

\section{Resumo}

A broncopneumonia é responsável por importantes perdas econômicas na produção bovina com maior impacto em pequenas produções, como a agricultura familiar. Dentre todas as possíveis causas da pneumonia bovina, os vírus são comumente categorizados como agentes etiológicos primários. O presente estudo teve como objetivo identificar a presença de Parainfluenza bovina tipo -3 (bPI-3V) e Influenzavirus D (IVD) por meio da PCR em Tempo Real em amostras de lavado traqueobrônquico de bezerros leiteiros saudáveis e com problemas respiratórios criados nos assentamentos do Estado de São Paulo, Brasil. As amostras foram colhidas em 42 pequenas propriedades de agricultura familiar. Ao todo, 141 amostras de lavado traqueobrônquico foram coletadas de bezerros sadios $(n=100)$ e com problemas respiratórios $(n=41)$. Nenhuma amostra foi positiva para nenhum dos vírus após PCR em Tempo Real. Soro neutralização para bPI-3v foi realizada em 88 amostras selecionadas randomicamente e anticorpos foram detectados em 45,45\% (40/88) das amostras. Amostras reagentes foram detectadas em ambos bezerros sadios $(46,8 \% ; 22 / 47)$ e bezerros com doença respiratória $(43,9 \% ; 18 / 41)$. Em relação ao título de anticorpos, diferenças foram detectadas entre sadios (3\%) e doentes $(9 \%)$ para título entre $128-512(\mathrm{P}>0.05)$. A presente pesquisa foi a primeira que avaliou a presença 
de bPI-3V e IVD em assentamentos do Estado de São Paulo, Brasil. Nosso estudo revelou que bPI-3V está circulando nos rebanhos daquela região, podendo estar associado a alguns casos de doença respiratória bovina. Não houve detecção de IVD nos rebanhos estudados.

Palavras-chaves: vírus; pneumonia; produção bovina; PCR em tempo real; lavado traqueobrônquico.

\section{Introduction}

Bovine respiratory disease (BRD) is responsible for high economic losses in dairy and beef cattle production (USDA, 2013), with major impact on family farming herds. Viruses are commonly categorized as primary etiological agents of BRD by changing respiratory mucosa, producing cytokines and impairing functioning of immune system cells (Bosch et al., 2013).

Bovine Parainfluenza type 3 virus (bPI-3v) belongs to order Mononegavirales and family Paramyxoviridae (ICTV, 2014). It is genetically and antigenically related to Human Parainfluenza type 3 virus (Murphy et al., 1999). Cattle infected by $\mathrm{bPI}-3 \mathrm{v}$ shows from asymptomatic to severe pneumonia symptoms. Allan et al. (1978) referred to dry cough as the first clinical sign observed in outbreaks, besides increasing on rectal temperature, inappetence, mucupurulent nasal discharge (Ellis, 2010), tachypnea, and tearing. Antibodies against bPI-3v have been detected in several countries, such as Canada (Durham and Hassard, 1990), Nigeria (Ib et al., 2005), Mexico (Solís-Calderón et al., 2007), Belgium (Pardon et al., 2011), Iran (Kojuri et al., 2011; Ezzi et al., 2013), Caribbean (Twari et al., 2016), Syria (Giangaspero et al., 1997), and Brazil (Candeias and Ribeiro, 1968; Sardi et al., 2010).

Recently, a virus with $50 \%$ homology with Human Influenza $\mathrm{C}$ virus was isolated from pigs (Hause et al., 2013), and bovines (Collin et al., 2015), and, after phylogenetic and serological analysis, it was classified as Influenza virus D (IVD). This new virus has already been detected in Italian (Chiapponi et al., 2016), French (Ducatez et al., 2015), and American (Hause et al., 2013) herds. Mitra et al. (2016) detected a tendency in association between IVD and bovine respiratory disease. To the best of our knowledge, there are no studies that aimed to detect the presence of IVD in Brazilian dairy herds.

Besides few studies that only evaluated the presence $b P I-3 v$, there are no researches that aimed to detect bPI-3v and IVD in family farming herd. Therefore, the present study aimed to identify the presence of bovine parainfluenza type 3 virus and Influenza virus D in tracheobronchial fluid samples of healthy calves and calves showing clinical signs of bovine respiratory disease breeding in family farming herds.

\section{Materials and Methods}

Area definition and sampling

The State of São Paulo is located in the southeast region of Brazil (21 ${ }^{\circ} 49^{\prime} \mathrm{S}$; $49^{\circ} 12^{\prime} \mathrm{W}$ ) and it has a dairy cattle population of $1,287,509$ (IBGE, 2014). Pontal do Paranapanema is located in the extreme west region of the State of São Paulo. The present study was carried out in three municipalities: Caiuá $\quad\left(21^{\circ} 49^{\prime} 55^{\prime}\right.$ 'S; $\left.51^{\circ} 59^{\prime} 52^{\prime \prime} \mathrm{O}\right)$, Presidente Epitácio (21 ${ }^{\circ} 45^{\prime} 53^{\prime \prime} \mathrm{S}$; $\left.52^{\circ} 06^{\prime} 19^{\prime \prime} \mathrm{O}\right)$ and Mirante de Paranapanema $\left(22^{\circ} 17^{\prime} 31^{\prime \prime} \mathrm{S} ; 51^{\circ} 54^{\prime} 21^{\prime \prime} \mathrm{O}\right)$. One-hundred and forty-one male and female, one to 12 months age, mongrel dairy calves were enrolled in this study. They received colostrum and milk from their mothers. After weaning, calves received pasture and mineral salt ad libitum.

Case definition and sample collection

Calves were randomly selected in each farm. Physical examination was performed in order to classify them as healthy calves and BRD calves. We considered BRD calves those that showed at least two of the following parameters: mucopurulent or purulent nasal discharge, cough, crackle, snoring, respiratory rate above 40 breaths per minute and rectal temperature above $39.5^{\circ} \mathrm{C}$ (Benesi et al., 2013).

Tracheobronchial fluid samples were collected after trichotomy and antisepsis of the trachea. An Intracath ${ }^{\circledR}$ (BD, New Jersey, USA) was introduced by tracheocentesis, and $20 \mathrm{~mL}$ of sterile saline $0.9 \%$ were instilled, recovering up to $5 \mathrm{~mL}$. A fraction was added to a dry cryogenic tube and immediately stored in nitrogen. Eight milliliters of total blood were obtained by jugular vein puncture using a dry $\mathrm{BD}$ vacutainer ${ }^{\circledR}$ tube. All tubes were centrifuged at $600 \times \mathrm{g}$ for 15 minutes and the serum obtained was stored in tubes at $-20^{\circ} \mathrm{C}$ until further analysis. 
Viral RNA was extracted from tracheobronchial fluid samples using MagMAXTM Viral RNA Isolation (Thermo Fisher Scientific Inc., Waltham, MA), according to manufacturer's instructions. For the bPI-3v and IDV detection, primers and probes used were designed by Horwood et al., (2008) and Horwood and Mahony (2011). All reactions were performed in a total volume of $15 \mu \mathrm{L}$ containing $3.5 \mu \mathrm{L}$ of Buffer; 0.25 $\mu \mathrm{L}$ enzyme (25X RT-PCR Enzyme Ambion); $1.0 \mu \mathrm{L}$ probe; $1.0 \mu \mathrm{L}$ of each primer (50 pmol), $5.25 \mu \mathrm{L}$ sterile deionized water and $5 \mu \mathrm{L}$ of RNA. Reactions were performed using OneStep StepOneTM Real-Time PCR System (Applied Biosystems, Thermo Fisher Scientific Inc., Waltham, MA), with the amplification cycle establish by Horwood and Mahony (2011). Results above the automatic threshold were considered positive. To ensure that samples were viable, samples were kept in nitrogen until laboratory analysis. Besides, the elution buffer used during the RNA extraction had an RNA preservative.

Serum-neutralization for bPI-3v

Serological tests were performed according to the Code of Federal Regulations (CFR, 2005). Briefly, the quantification of antibodies started from 1:2 to $1: 256$ in 96-well plates. Then, 100 TCID50/50mL were added to bPI-3v (ATCC VR 281). All plates were incubated at $37^{\circ} \mathrm{C}$ with $5 \%$ $\mathrm{CO} 2$ for one hour. After that, bovine kidney epithelial cell (MDBK) suspension was added and plates were incubated again in same conditions for 72 hours. Antibody titers were expressed as the inverse of the dilution where absence of cytopathic effect was observed. Samples with titers equal or higher than three were considered reactive. Serum neutralization tests were validated through the control of negative and positive sera for anti-BVDV antibodies, control of cells, and retrotitration plate, according to Reed e Muench (1938).

Statistical analysis

Descriptive results were provided. All results were analyzed using Chi-square test and Fisher's Exact Test and Odds Ratio using JMP Pro 12 (SAS Institute Inc., NC). A confidence interval of $90 \%$ was used. Results showing $\mathrm{P}<$ 0.01 were considered significant.

\section{Results}

Samples were collected between 2014 and 2015 from 42 small farms located in Caiuá, Presidente Epitácio, and Mirante do Paranapanema. Hundred and forty-one calves were enrolled in this study and classified as healthy $(n=100)$ and BRD calves $(n=41)$. No sample was positive for either viruses by RealTime PCR (Data not shown). Serumneutralization for bPI-3v was performed using 88 randomly selected serum samples (47 healthy and 41 BRD calves). Antibodies were detected in $45.45 \%$ (40/88) samples. Serum reactive samples were detected in both healthy calves $(46.80 \%$; 22/47) and BRD calves (43.90\%; 18/41). Regarding antibody titer, numerical differences were detected between healthy (3\%) and BRD calves (9\%) for titers 128 to $512(\mathrm{P}>0.05)$. On the other hand, antibody titers between 2 and 8 were numerically higher in healthy $(22 \%)$ calves compared to BRD calves (17\%) (Figure 1).

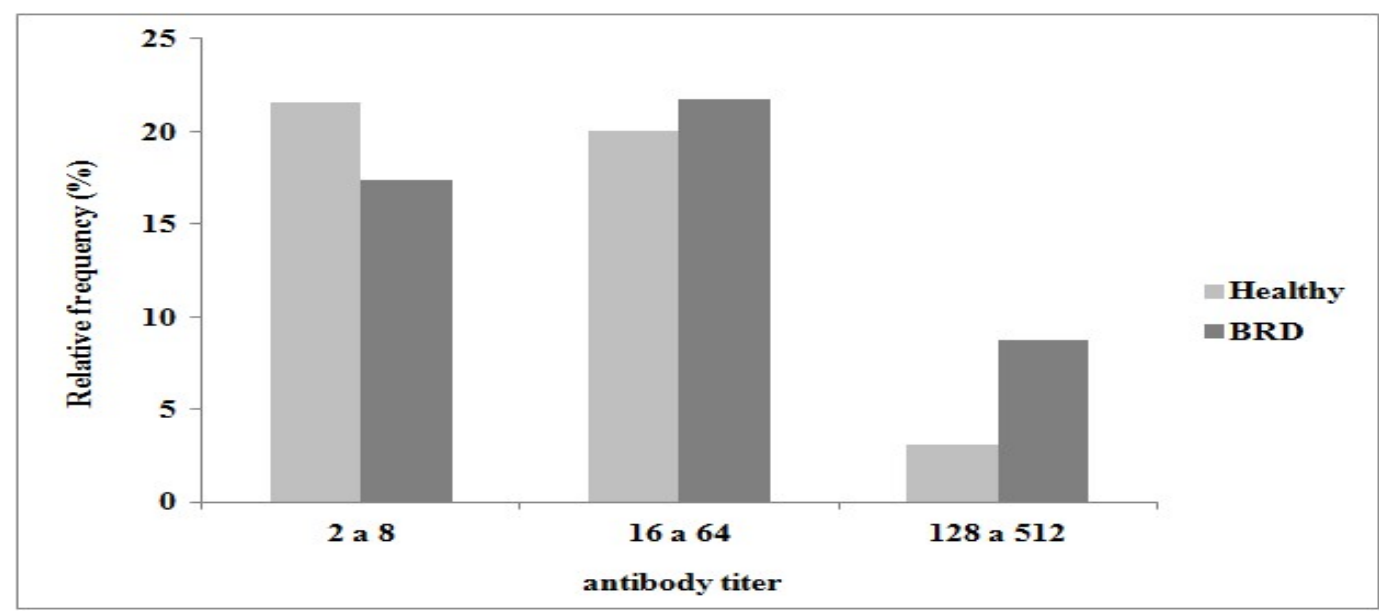

Figure 1. Antibody titers against bPI-3v detected in healthy and BRD calves by serum neutralization. 


\section{Discussion}

Respiratory diseases are characterized as a multi-factorial condition (Griffin et al., 2010) that contributes to the failure of the calf breeding (Autio et al., 2007). Intracellular viral replication is responsible for cellular lysis (Bosch et al., 2013) and disorders in immune cells functionality. In an effort to detect the presence of bPI-3v and IVD in settlements from Pontal do Paranapanema, São Paulo State, Brazil, Real-Time PCR was performed using tracheobronchial fluid samples of healthy and BRD calves, besides serum neutralization tests.

In the present study, bPI-3v and IVD were not detected in tracheobronchial fluid samples of both healthy and BRD calves. The detection of the antigen in Brazilian cattle was only described in the States of São Paulo (SP) and Rio Grande do Sul (RS). Candeias and Ribeiro (1971) reported the first isolation of bPI-3v in Brazil from pulmonary tissue with pneumonic lesions of bovines in SP. On the other hand, Gonçalves et al. (2003) isolated bPI-3v from nasal discharge of a bovine with respiratory disease in RS, indicating that bPI-3v can be detected in both upper and lower respiratory tract.

Serum neutralization was performed for bPI-3v in samples randomly selected and antibodies were detected in $45.45 \%$ samples. The first indication of the presence of bPI-3v in Brazil was reported in 1968 by Candeias and Ribeiro (1968), in which study $36.71 \%$ of cattle showed antibodies against bPI-3v by inhibition of hemagglutination. Using same serological test, Sardi et al. (2010) detected antibodies in $68.5 \%$ samples in the State of Bahia. Our results demonstrate that bPI-3v is present in herds from Pontal do Paranapanema and it addresses the need for constant monitoring. It is well known that bPI$3 \mathrm{v}$ is an important primary agent of BRD, although this virus predisposes to secondary bacterial infection (Ellis, 2010). The detection of antigen is possible when the animal has an active infection. The presence of antibodies against bPI$3 \mathrm{v}$ in addition to the failure to detect the antigen could be related to the possibility of animals show a regressive infection and have developed specific immune responses (Griffin et al. 2010).

To the best of our knowledge, this is the first study that aimed to detect Influenza virus D in Brazilian herds by molecular approaches. The presence of IVD was already reported in the
United States (Hause et al., 2013, Ferguson et al., 2015), Italy (Chiapponi et al., 2016), and France (Ducatez et al., 2015). There is no evidence that this virus is circulating in South America, especially in those countries bordering Brazil. To the authors' knowledge, no antibody test for IVD is available. Considering IVD as a new species, more information is required to better understand its pathology, cross-reactivity to other influenza viruses and epidemiology.

\section{Conclusion}

The present research was the first that evaluated the presence of bPI-3v and IVD in family farming farms located in São Paulo State, Brazil. Our research revealed that bPI-3v seems to be important to pneumonia cases in that place. Moreover, studies should be expanded to better understand the importance of bPI- $3 \mathrm{v}$ and to confirm the absence of IVD in Brazilian family farming dairy herds.

\section{Conflict of Interest}

The authors have no competing interests.

\section{Ethics statement}

The present study was conducted at the Laboratory of Clinical and Molecular Virology from Institute of Biomedical Sciences, Laboratory of Bovine Virology from the Biologic Institute, at the School of Veterinary Medicine and Animal Science, University of São Paulo, Brazil, from August 2014 until March 2016. All procedures were carried out in agreement with the guidelines Committee of Ethics on Animal Use (Protocol number: 7973040214).

\section{Acknowledgements}

We would like to thank São Paulo Research Foundation (protocol\# 2014/03188-3) and Coordination of Improvement of Higher Education Personnel (CAPES) for the financial support, and São Paulo Land Institute (ITESP) for the opportunity to study the settlements. We are also thankful to Dr. Edviges Maristela Pituco from Laboratory of Bovid Viruses, Biological Institute, for kindly provide the positive control for PCR.

\section{References}

Allan, E.M.; Pirie, H.M.; Selman, I.E.; Snodgrass, D.R. Some characteristics of a natural infection by parainfluenza-3 virus in a group 
of calves. Research in Veterinary Science, 24(3): 339-346, 1978.

Autio, T.; Pohjanvirta, T.; Holopainen, R.; Rikula, U.; Pentikainen, J.; Huovilainen, A.; Rusanen, H.; Soveri, T.; Sihvonen, L.; Pelkonen, S. Etiology of respiratory diseased in non-vaccineted, non-medicated calves in rearing herds. Veterinary Microbiology, 119(2-4): 256-265, 2007.

BRASIL. Instituto Brasileiro de Geografia e Estatística. 2014. Disponível em <www.ibge.gov.br>. Acesso em: 21 ago. 2017.

Benesi, F.J.; Bertagnon, H.G.; Wachholz, L.; Leal, M.L.R.; Fernandes,W.R.; Benites, N.R.; Melville, P.A. Microbiota bacteriana e citologia da região traqueobrônquica de bezerros no período neonatal. Pesquisa Veterinária Brasileira, 33(6):700-704, 2013.

Bosch, A.A.T.M.; Biesbroek, G.; Trzcinski, K.; Sanders, E.A.M.; Bogaert, D. Viral and bacterial interactions in the upper respiratory tract. PLoS Pathogens, 9(1), e1003057, 2013.

Candeias, J.A.N.; Ribeiro, L.C. Anticorpos inibidores da hemaglutinação para o vírus parainfluenza 3 (Ha-1), em gado bovino. Revista de Saúde Pública, 2(2):180-185, 1968.

Candeias, J.A.N; Sugay, W.; Ribeiro, L.C. Isolation of Myxovirus parainfluenza 3 from cattle in the State of São Paulo, Brazil. Revista de Saude Publica, 5:207-212, 1971.

Chiapponi, C.; Faccini, S.; De Mattia, A.; Baioni, L.; Barbieri, I.; Rosignoli, C.; Nigrelli, A.; Foni, E. Detection of influenza D virus among swine and cattle, Italy. Emergence Infectious Disease, 22(2): 352-354, 2016.

Collin, E.A.; Sheng, Z.; Lang, Y.; Ma, W.; Hause, B.M.; Li, F. Cocirculation of two distinct genetic and antigenic lineages of proposed influenza $D$ virus in cattle. Journal of Virology, 89(2): 1036-1042, 2015.

Durham, P.J.; Hassard, L.E. Prevalence of antibodies to infectious bovine rhinotra-cheitis, parainfluenza 3 , bovine respiratory syncytial, and bovine viral diarrea viruses in cattle in Saskatchewan and Alberta. Canadian Veterinary Journal, 31(12): 815-820, 1990.

Ellis, J.A. Bovine parainfluenza-3 Virus. Veterinary Clinics of North America:
Food Animal Practice, 26(3): 575-593, 2010.

Ducatez, M.F.; Pelletier, C.; Meyer, G. Influenza D virus in cattle, France, 2011-2014. Emergence Infectious Disease, 21(4): 368$371,2015$.

Ezzi, A.; Hatami, A.; Bahshesh, M.; Shoukri, M.R.; Gharaghozloyan, M. Serological survey of bovine herpesvirus type 1 and parainfluenza type 3 in cow farms of Qazvin province based on different ages and seasons. Archives of Razi Institute, 68(1): 53-57, 2013.

Ferguson, L.; Eckard, L.; Epperson, W.B.; Long, L.-P.; Smith, D.; Huston, C.; Genova, S.; Webby, R.; Wan, X.-F. Influenza D virus infection in Mississippi beef cattle. Virology, 486: 28-34, 2015.

Filoni, C.; Catão-Dias, J.L.; Bay, G.; Durigon, E.L.; Jorge, R.S.P.; Lutz, H.; HofmannLehmann, R. First evidence of feline herpesvirus, calicivirus, parvovirus, and ehrlichia exposure in Brazilian free-ranging felids. Journal of Wildlife Disease, 42(2): 470-477, 2006.

Giangaspero, M.; Vanopdenbosch, E.; Nishikawa, H.; Tabbaa, D. Prevalence of antibodies against respiratory viruses (Parainfluenza type 3, respiratory syncytial virus, reovirus and adenovirus) in relation to productivity in Syrian Awassi sheep. Tropical Animal Health and Production, 29(2): 83-91, 1997.

Gonçalves, D.A.; Spilki, F.R.; Chiminazzo, C.; Oliveira, M.A.; Franco, A.C.; Roehe, P.M. Isolamento do vírus Parainfluenza bovino tipo 3 no Rio Grande do Sul, Brasil. Ciência Rural, 33(5): 953-956, 2003.

Griffin, D.; Chengappa, M.M.; Kuszak, J.; McVey, D.S. Bacterial pathogens of the bovine respiratory disease complex. Veterinary Clinics of North America: Food Animal Practice, 26: 381-394, 2010.

Hause; B.M.; Ducatez, M.; Collin, E.A.; Ran, Z.; Liu, R.; Sheng, Z.; Armien, A.; Kaplan, B.; Chakravarty, S. Isolation of a novel swine influenza virus from Oklahoma in 2011 which is distantly related to human influenza C viruses. PLoS Pathogen, 9(2): e1003176, 2013.

Horwood, P.F.; Gravel, J.L.; Mahony, T.J. Identification of two distinct bovine parainfluenza virus type 3 genotypes. 
Journal of General Virology, 89(7): 1643$1648,2008$.

Horwood, P.F.; Mahony, T.J. Multiplex real-time RT-PCR detection of three viruses associated with the bovine respiratory disease complex. Journal of Virology Methods, 171(2): 360363, 2011.

Ibu, M.; Salihu, E.A.; Abechi, M.A.; AbaAdulugba, E.P.; Okewu, M. Activity of bovine parainfluenza type 3 virus in cattle in north eastern Nigeria-a short communication. Journal of Veterinary Science, 6: 1-4, 2005.

International Committee on Taxonomy of Viruses (ICTV). 2014. Disponível em <ictvonline.org>. Acesso em: 21 ago. 2017.

Kojuri, G.A.; Hemmatzedeh, F.; Taghadosi, C. Serological survey on bovine parainfluenza type 3 in Shahrekpord district (Iran). Comparative Clinical Pathology, 20(3): 201-204, 2011.

Mitra, N.; Cernicchiaro, N.; Torres, S.; Li, F.; Hause, B.M. Metagenomic characterization of the virome associated with bovine respiratory disease in feedlot cattle identified novel viruses and suggests an etiologic role for influenza D virus. Journal of General Virology, 97(8):1771-1784, 2016.

Reed, L.J.; Muench, H. A simple method of estimating fifty per cent endpoints. The American Journal of Hygiene, 27(3): 493497, 1938.

Murphy, F.A.; Gibbs, E.P.J.; Horzinck, M.C.; Studdert, M.J. Paramyxoviridae. In:

Veterinary virology. 1999. p.411-428.

Oem, J.-K.; Lee, E.-Y.; Lee, K.-K.; Kim, S.-H.; Lee, M.-H.; Hyun, B.-H. Molecular characterization of a Korean bovine parainfluenza virus type 3 isolate. Veterinary Microbiology, 162(1): 224-227, 2013.

Pardon, B.; de Bleecker, K.; Dewulf, J.; Callens, J.; Boyen, F.; Catry; B.; Deprez, P. Prevalence of respiratory pathogens in deseased, non-vaccinated, routinely medicated veal calves. Veterinary Record, 169(11): 278, 2011.

Resinger, R.C.; Heddleston, K.L.; Manthel, C.A. A myxovirus (SF-4 associated with shipping fever of cattle. Journal of American Veterinary Medical Association, 135(3): 147-152, 1959.

Sardi, S.I.; Campos, G.S.; Barros, S.B.; Edelweiss, G.L.; Martins, D.T. Detecção de anticorpos contra o vírus da parainfluenza bovina tipo 3 (PI-3) e o vírus da leucose bovina (vlb) in bovinos de diferentes municípios do estado da Bahia, Brasil. Revista de Ciências Médicas e Biológicas, 1(1): 62-65, 2010.

Solís-Calderón, J.J.; Segura-Correa, J.C.; AguilarRomero, F.; Segura Correa,V.M. Detection of antibodies and risk factors for infection with bovine respiratory syncytial virus and parainfluenza virus-3 in beed cattle of Yucatan, Mexico. Preventive Veterinary Medicine, 82(1-2): 102-110, 2007.

Twari, K.; Cornish, C.; Gamble, B.; Thomas, D.; Sharma, R.N. Seroprevalence of bovine parainfluenza virus type 3 (bPI-3V) in ruminants from granada. Open Journal of Veterinary Medicine, 6(2): 23-27, 2016.

UNITED STATES OF AMERICA. USDA. Feedlot 2001. Part IV: Health and Health Management on U.S. Feedlots with a capacity of 1,000 or more head. In: APHIS. Fort Collins: National Animal Health Monitoring System. 2013. Disponível em: < https://www.aphis.usda.gov/animal_health/na hms/feedlot/downloads/feedlot2011/Feed11_ dr_PartIV.pdf >. Acesso em: 21 ago. 2017.

Zhu, Y.-M.; Shi, H.-F.; Gao, Y.-R.; Xin, J.-Q.; Liu, N.-H.; Xiang, W.-H.; Ren, X.-G.; Feng, J.-K.; Zhao, L.-P.; Xue, F. Isolation and genetic characterization of bovine parainfluenza virus type 3 from cattle in China. Veterinary Microbiology, 149(3-4): 446-451, 2011. 